\title{
Methotrexate Changes the Testicular Tyrosine Phosphorylated Protein Expression and Seminal Vesicle Epithelia of Adult Rats
}

\author{
El Metotrexato Cambia la Expresión de la Proteína Testicular-Tirosina \\ Fosforilada y el Epitelio Vesicular seminal en Ratas Adultas
}

\begin{abstract}
Sitthichai Iamsaard ${ }^{1,2}$;Jariya Umka Welbat ${ }^{1}$; Wannisa Sukhorum ${ }^{3}$; Suchada Krutsri' ${ }^{1}$; Supatcharee Arun ${ }^{1,2} \&$ Tarinee Sawatpanich ${ }^{1,2}$
\end{abstract}

\begin{abstract}
IAMSAARD, S.; WELBAT, J. U.; SUKHORUM, W.; KRUTSRI, S.; ARUN, S. \& SAWATPANICH, T. Methotrexate changes the testicular tyrosine phosphorylated protein expression and seminal vesicle epithelia of adult rats. Int. J. Morphol., 36(2):737-742, 2018.

SUMMARY: Methotrexate (MTX) is commonly used as a chemotherapy agent and immune system suppressant but its adverse effect on male reproductive system is still limited. This study aimed to investigate the effect of MTX on structure and functional proteins of testis and seminal vesicle. Adult male rats were divided into control and MTX groups $(\mathrm{n}=12)$. In 30 experimental days, the treated animals were injected with MTX (tail i.v., $75 \mathrm{mg} / \mathrm{KgBW}$ ) at days 8 and 15 . Then, the reproductive parameters and histology of both groups were examined. Thickness of seminal seminal vesicle epithelia was analyzed. Also, the expressions of testicular tyrosine phosphorylated proteins and steroidogenic acute regulatory (StAR) protein were investigated. The results showed that MTX could significantly decrease epididymal sperm concentration. In addition, the germ cell degeneration, increased spaces of interstitial tissues, and low epididymal sperm mass density were observed in MTX group. The thickness of seminal vesicle epithelia in MTX group was significantly lower than that of control group. Moreover, the intensity of testicular phosphorylated proteins of 31, 32, 72, and 85 kDas was significantly increased while of 42 and $47 \mathrm{kDas}$ in MTX group was decreased as compared to control. The expression of testicular StAR protein in MTX group was also significantly decreased as compared to the control. In conclusion, MTX affects testicular and seminal tissues and changes testicular functional proteins in adult rats.
\end{abstract}

KEY WORDS: Methotrexate; Phosphorylated proteins; Testis; Seminal vesicle; Male rat.

\section{INTRODUCTION}

Recently, it has been known that many chemotherapeutic agents in cancer treatment can cause acute toxicity on vital organs (Kim et al., 1999). Particularly, such agents have been demonstrated to result in azoospermia and infertility (Schilsky et al., 1980; Iamsaard et al., 2017; Sukhorum \& Iamsaard, 2017) because they have anti-cell division and anti-proliferative activities. Methotrexate (MTX) is a folate antagonist (Saxena et al., 2009). It is commonly used as a chemotherapy drug and immune system suppressant. Although MTX is used in treating of many cancers and for rheumatoid arthritis, its side effects have been reported in many systems including bone marrows, liver, lungs, kidneys, gastrointestinal, central nervous, and reproductive systems (Gibson \& Bowen, 2011; Argyriou et al., 2012; Blumenfeld, 2012). Previous studies in male reproductive system have demonstrated that MTX can damage seminiferous tubules resulted in disorganization and vacuolization of germinal epithelium (Johnson et al., 1994; Chelab \& Majeed, 2009). MTX also could decrease sperm number and damage sperm DNA (Padmanabhan et al., 2009; Vardi et al., 2009; Yulug et al., 2013). The reports showing effect of MTX on spermatogenesis and steroidogenesis are still limited (Shrestha et al., 2007; Padmanabhan et al., 2008). Indeed, the adverse effects of MTX on seminal vesicle and testicular functional proteins, especially tyrosine phosphorylated and steroidogenic acute regulatory (StAR) proteins, have never been documented. Therefore, we have attempted to demonstrate the side effects of MTX on the structural and functional protein changes of testis and seminal vesicle of adult male rats.

\footnotetext{
${ }^{1}$ Department of Anatomy, Faculty of Medicine, Khon Kaen University, 123 Mittraphap Road Road, Amphoe Maung, District, Khon Kaen, 40002, Thailand. ${ }^{2}$ Reproductive Biomedicine Research Unit, Faculty of Medicine, Khon Kaen University, 123 Mittraphap Road Road, Amphoe Maung, District, Khon Kaen, 40002, Thailand.

${ }^{3}$ School of Medicine, Mae Fah Luang University, Chiang Rai, 57100, Thailand.
} 


\section{MATERIAL AND METHOD}

Animals and treatment. This study has utilized the rest reproductive samples from a research project kindly provided by associate professor Dr. Jariya Umka Welbat, Department of Anatomy, Faculty of Medicine, Khon Kaen University. In brief, twenty four adult male Sprague Dawley rats (200$230 \mathrm{~g}$ ) were purchased from the National Laboratory Animal Center, Salaya, Nakhon Pathom, Thailand. The animals were housed within polycarbonate cages in the animal experiment room with a constant temperature $\left(22 \pm 2{ }^{\circ} \mathrm{C}\right)$ under a 12-h light-dark cycle, in North-East Laboratory Animal Center, Khon Kaen University, Thailand. All rats had ad libitum access to a commercial pellet diet and water. Rats were randomly divided into control and methotrexate (MTX) treated groups ( $\mathrm{n}=12$ each). In 30 experimental days, the MTX-treated animals were injected with MTX (tail i.v., 75 $\mathrm{mg} / \mathrm{KgBW}$ ) two times, at days 8 and 15 , followed by leucovolin injection to rescue the toxic flow rate while the control rats were injected with normal saline. After experimental end, all reproductive organs were collected for further investigations. This study was approved by Animal Ethics Committee of Khon Kaen University, based on the Ethics of Animal Experimentation of National Research Council of Thailand (Record No. ACUC-KKU-46/2559, Ref. No. 0514.1.75/51).

Reproductive organ weight analysis. The testis, epididymis plus vas deferens, and seminal vesicle plus prostate gland from control and MTX-induced animals were dissected. After removal of fat pad surrounding such tissues, all reproductive organs were immediately weighed on a sensitive digital balance to be recorded as absolute organ weight $(\mathrm{g})$. These organ weights were further calculated as individual relative organ weights using a formulation of one hundred multiplied by the absolute weight of reproductive organ and divided with mice body weight ( $\mathrm{g}$ of organ $/ 100 \mathrm{~g}$ $\mathrm{BW})$.

Histological examination. The testes, caudal epididymis, and seminal vesicle were fixed in $10 \%$ phosphate buffered formalin ( $\mathrm{pH}$ 7.4) for $48 \mathrm{~h}$. Then, the fixed tissues were routinely processed for light microscope examination using automatic tissue processing at the Pathology Department, Faculty of Medicine, Khon Kaen University. In subsequent, the paraffinized-tissue blocks were sectioned at 5-7 $\mu \mathrm{m}$ thickness and stained by hematoxylin and eosin. The stainedtissue slides were dehydrated in series of graded ethanol alcohols (70\%, $80 \%, 90 \%$, and $100 \%$, respectively), cleared in xylene, and mounted using DPX before observation under light microscope. The histological sections were captured by Nikon light ECLIPSE E200 microscope equipped with a DXM1200 digital camera to observe the histopathological changes of testis, caudal epididymis, and seminal vesicle between the MTX and control groups.

Thickness analysis of seminal vesicle epithelia. The epithelial thickness was determined by averaging the epithelial thickness of seminal vesicle epithelium from basement membrane to apical surface of the simple columnar cell as shown in Figure 2A. Ten tissue sections of each animal were randomly selected and ten interval serial sections were used to be measured. The ImageJ (ver. 1.4.3.67) program was applied in thickness analysis.

Western blot analysis. The right testis was homogenized with RIPA buffer (Cell Signaling Technology, Inc., USA) containing a protease inhibitor cocktail (Sigma-Aldrich, Inc., USA). The total protein concentration was measured by using a NanoDrop ND-1000 Spectrophotometer (NanoDrop Technologies, Inc., USA) at an absorbance of $280 \mathrm{~nm}$. All testicular proteins were separated in $12 \%$ SDS-PAGE gel. The separated proteins were transferred onto nitrocellulose membrane and incubated with $5 \%$ skim-milk blocking solution before incubation with anti-phosphotyrosine $4 \mathrm{G} 10$ antibody (1: $1000(\mathrm{v} / \mathrm{v})$; Millipore) or anti-StAR antibody (1: 2000 (v/v); Santa Cruz Biotechnology). After membranes were washed out for non-specific binding, they were incubated with a horseradish peroxidase-conjugated secondary antibody specific to each primary antibody. Positive expression of target proteins was detected using an enhanced chemiluminescence (ECL) substrate kits (GE Healthcare Life Sciences). The protein bands were explored by ImageQuant 400 imaging system (GH Healthcare Life Sciences). The intensity of protein bands was quantified using ImageJ program. The bovine serum albumin (BSA; Millipore), epidermal growth factor (EGF; Millipore) and StAR lysate were used as a negative or positive control.

Statistical analysis. All data were first tested for normal distribution. For consideration of significant differences between 2 groups, the $t$-test was used for normal data distribution while Mann-Whitney test (non-parametric test) was used for abnormal distribution. All data are expressed as mean \pm standard deviation (S.D.). $P<0.05$ was considered for significant difference.

\section{RESULTS}

Effect of MTX on reproductive organs and sperm concentration. The results showed that MTX did not acutely affect the body weight of male mice (Table I). For reproductive organ weights, MTX could significantly 


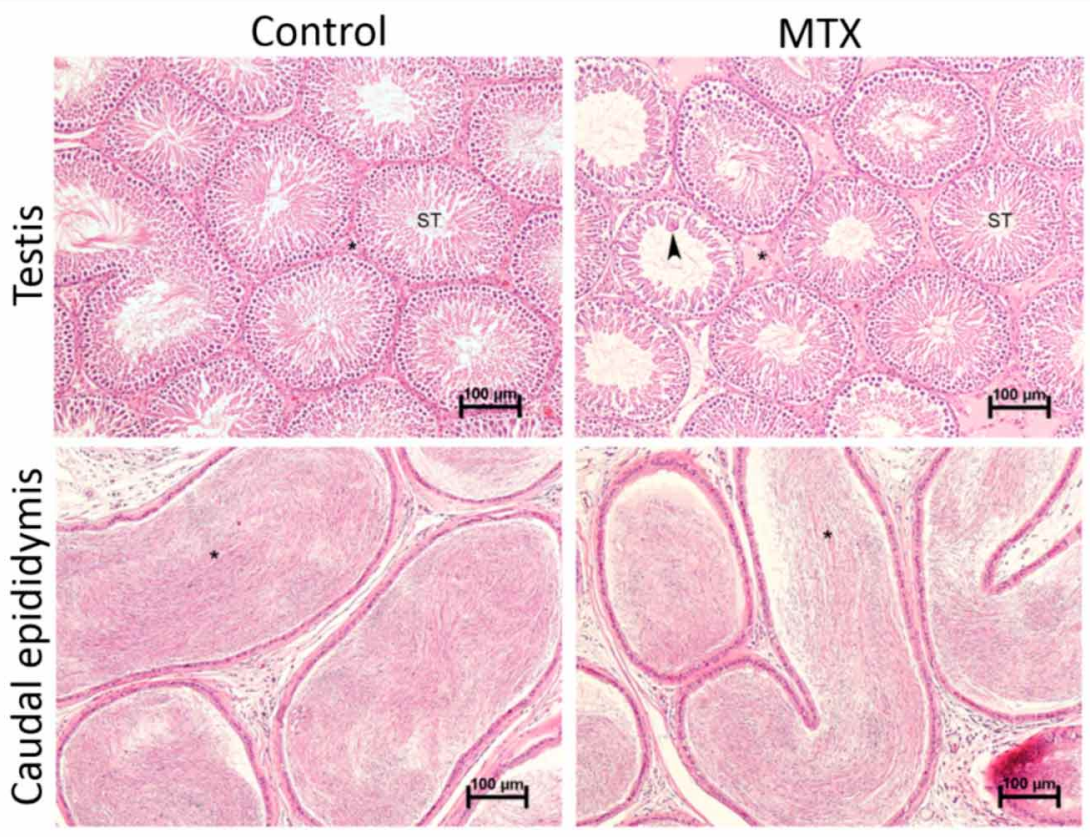

Fig. 1. Showing histology of testis (upper row) and caudal epididymis (lower row) tissues of control (left panel) and methotrexate (MTX; right panel). In testis, interstitial tissue space (asterisks); seminiferous tubule (ST); multinucleated giant germ cell (arrow head) within atrophic seminiferous tubule. In caudal epididymis, sperm mass density (asterisks).

decrease the absolute weight of testis and seminal vesicle plus prostate gland (Table I). Although the weight of epididymis plus vas deferens of both control and MTX groups is not different, the sperm concentration in MTX group was significantly decreased as compared to that of control (Table I).

Effects of MTX on testicular histology and epididymal sperm mass density. Figure 1 showed the histology of testis and epididymis of control and MTX groups. It was found that MTX could damage testicular tissue compared to the control. The germ cell degeneration with giant multi nucleated cells within atrophic seminiferous tubules and increased spaces of interstitial tissues were observed in MTX group (Fig. 1). Moreover, the epididymal sperm mass density in MTX group seemed to be lower than that of control group (Fig. 1).

Effects of MTX on seminal vesicle epithelial changes. The histology and thickness of seminal vesicle epithelia of control and MTX-treated groups were shown in Figure 2. It was obviously demonstrated that the epithelial height in MTX

Table I. Showing the weights of body and male reproductive organs and epididymal sperm concentration of control and methotrexate (MTX)-treated rats.

\begin{tabular}{lcc}
\hline Parameters & Control & MTX \\
\hline Body weight $(\mathrm{g})$ & $409 \pm 22$ & $408 \pm 19$ \\
Testis & & \\
$\quad$ Absolute weight $(\mathrm{g})$ & $1.85 \pm 0.1$ & $1.70 \pm 0.11^{*}$ \\
$\quad$ Relative we ight $\left(\mathrm{g} 100 \mathrm{~g}^{-1}\right)$ & $0.45 \pm 0.02$ & $0.43 \pm 0.03$ \\
Epididymis + vas deferen s & & \\
$\quad$ Absolute weight $(\mathrm{g})$ & $0.65 \pm 0.06$ & $0.62 \pm 0.04$ \\
$\quad$ Relative we ight $\left(\mathrm{g} 100 \mathrm{~g}^{-1}\right)$ & $0.16 \pm 0.01$ & $0.16 \pm 0.01$ \\
S eminal vesicle + prostate gland & & \\
$\quad$ Absolute weight $(\mathrm{g})$ & $2.04 \pm 0.16$ & $1.87 \pm 0.16^{*}$ \\
$\quad$ Relative we ight $\left(\mathrm{g} 100 \mathrm{~g}^{-1}\right)$ & $0.50 \pm 0.03$ & $0.47 \pm 0.03^{*}$ \\
Sperm concentration $\left(\mathrm{x} 106\right.$ cells $\left./ \mathrm{mL}^{-1}\right)$ & $77.44 \pm 3.42$ & $32.92 \pm 4.27^{*}$ \\
\hline
\end{tabular}

* Significant difference; $\mathrm{p}<0.05$ (t-test) compared to the control. 
A
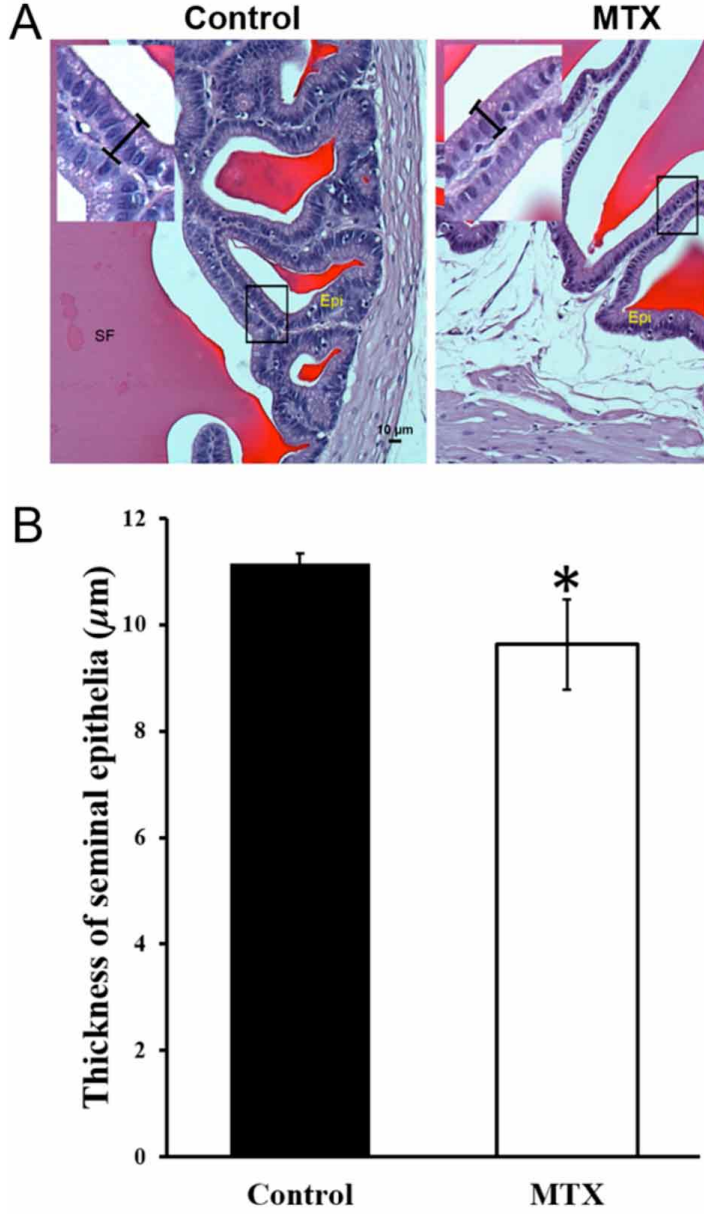

Fig. 2. Showing histology of seminal vesicle (A) and thickness of seminal epithelial (B) tissues of control and methotrexate (MTX). Epithelium (Epi); seminal vesicle fluid (SF). * Significant difference; $\mathrm{p}<0.05$ as compared to control.

group was lower than that of control group (Fig. 2A). Indeed, it was confirmed by the quantified results that the thickness of seminal vesicle epithelia of MTX group was significantly shorter as compared to that of control (Fig. 2B). However, the other abnormal cells were not observed in MTX group.

Effects of MTX on tyrosine protein phosphorylation in testis. The profiles of the equal total testicular protein lysate of both groups were not changed to each other (Fig. 3A). Interestingly, it was found that the patterns of testiculartyrosine phosphorylated proteins in MTX group were obviously different from that of control revealed by western blotting (Fig. 3B). In comparisons, the results showed that the intensity of testicular phosphorylated proteins of 31, 32, $72,85 \mathrm{kDas}$ in MTX group was significantly increased as compared to that in control group (Fig. 3C). In contrast, the
A

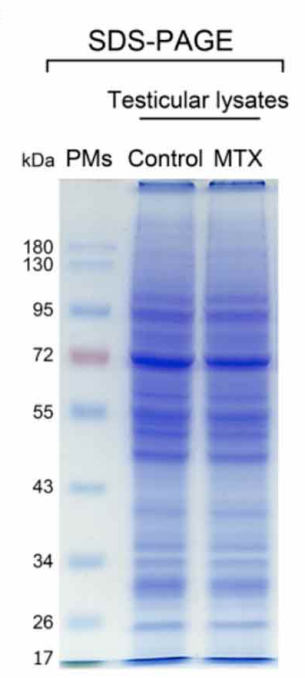

B

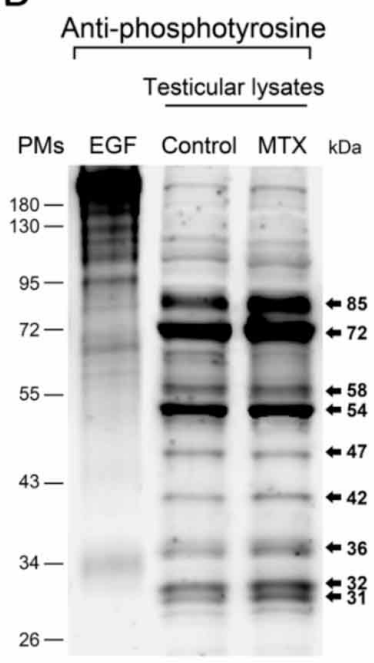

C

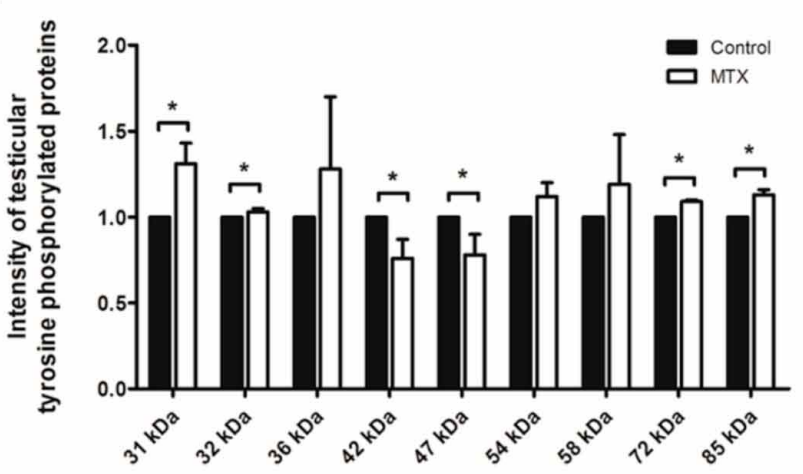

Fig. 3. Showing testicular protein profiles revealed by SDS-PAGE stained by Coomassie blue dye (A), immuno-western blotting against tyrosine phosphorylated proteins (B), and intensity of testicular tyrosine phosphorylated proteins (C) of control and methotrexate (MTX). Pre-stained markers (PMs); epididymal growth factor (EGF) lysate used as a positive control; kilo Dalton $(\mathrm{kDa})$. * Significant difference; $\mathrm{p}<0.05$ compared to the control

intensity of 42 and 47 kDas in MTX group was significantly decreased as compared to control. However, the expression of 36,54 , and $58 \mathrm{kDas}$ phosphorylated protein in both groups was not different to each other (Fig. 3C).

Effects of MTX on testicular StAR protein expression. The results showed that the expression of testicular StAR protein in MTX group was not different from that of the control (Fig. 4A). However; using beta actin as an internal control to be calculated for intensity, it was found that MTX could significantly decrease the StAR protein expression as compared to the control (Fig. 4B). 


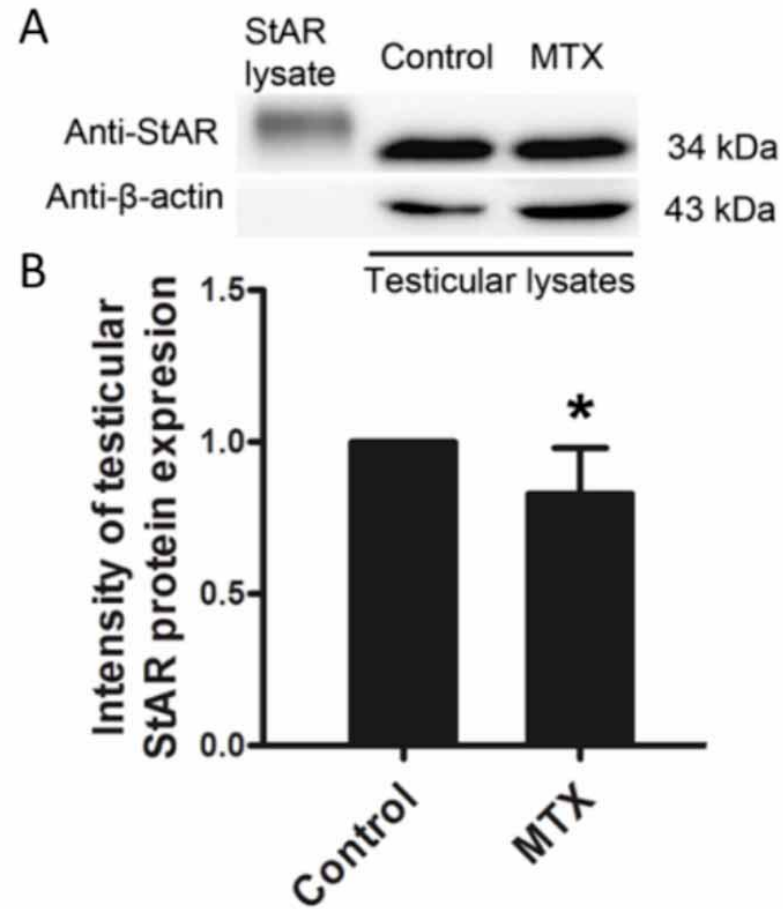

Fig. 4. Showing immuno-western blotting of testicular protein lysate against steroidogenic acute regulatory (StAR) protein and beta actin used as internal control (A) and intensity of testicular StAR protein expression (B) of control and methotrexate (MTX). Prestained markers (PMs); epididymal growth factor (EGF) lysate used as a positive control; kilo Dalton (kDa). * Significant difference; $\mathrm{p}<$ 0.05 as compared to the control

\section{DISCUSSION}

Recent study has shown that MTX did not affect the body weight but could decrease the weights of testis and seminal vesicle. This result indicates that MTX has direct effect on male reproductive organs responsible for sperm and seminal productions. It is possible to explain why the sperm mass density within caudal epididymis of MTX group was lower than that of control. Indeed, it corroborated with significant decrease of sperm concentration as also described in previous reports (Shrestha et al.; Padmanabhan et al., 2008, 2009; Vardi et al.; Sukhotnik et al., 2013; Yulug et $a l$.). The histopathology found in this study is similar to that of previous observations (Johnson et al.; Chelab \& Majeed; Maremanda \& Jena, 2017). It also seemed that the degrees of seminiferous damages are comparable to other chemotherapeutic agents (Schilsky et al.; Sukhorum \& Iamsaard; Iamsaard et al., 2017). Taken together with reduction of reproductive organ weight and sperm production, MTX may deprive the serum testosterone level as descried previously (Akindele et al., 2015). Although the decrease of testosterone level induced by MTX in this study was not determined, it was confirmed by reduction of StAR protein/ actin expressions (Fig. 3). For the first time, we have demonstrated the effect ofMTX on thickness of seminal vesicle epithelia and changes of testicular tyrosine phosphorylated proteins. The low epithelia thickness of seminal vesicle could cause abnormal secreting of seminal fluid including catalase expression and lipid peroxidation (Mitropoulos et al., 2013). The tyrosine phosphorylation in the testis is assumed to be essential for spermatogenesis and testosterone production. Previous reports have suggested that the changes of patterns of testicular phosphorylated proteins are associated with reduction of sperm concentrations (Iamsaard et al., 2014; Arun et al., 2016a,b; Iamsaard et al., 2017; Sukhorum \& Iamsaard). Interestingly, MTX also could change the expression patterns of the testicular phosphorylated proteins by significant increasing of 31,32 , $72,85 \mathrm{kDas}$ in MTX group was significantly increased while decreased intensity of 42 and $47 \mathrm{kDas}$ as compared to control (Fig. 3). We assumed that such changed proteins may play important roles in spermatogenesis and testosterone production. However, the identification of those proteins to elucidate the physiological functions must be further investigated. To our knowledge, it is concluded that MTX alters seminal vesicle epithelium and changes of testicular tyrosine phosphorylated proteins.

\section{ACKNOWLEDGEMENTS}

This study was funded by the invitation research grant, Faculty of Medicine, Khon Kaen University, Thailand (Grant Number IN60250) to Dr. Sitthichai Iamsaard.

IAMSAARD, S.; WELBAT, J. U.; SUKHORUM, W.; KRUTSRI, S.; ARUN, S. \& SAWATPANICH, T. El metotrexato cambia la expresión de la proteína testicular-tirosina fosforilada y el epitelio vesicular seminal en ratas adultas. Int. J. Morphol., 36(2):737-742, 2018.

RESUMEN: El metotrexato (MTX) se usa comúnmente como agente de quimioterapia y supresor del sistema inmunitario, pero su efecto adverso en el sistema reproductor masculino sigue siendo limitado. Este estudio tuvo como objetivo investigar el efecto del MTX sobre la estructura y las proteínas funcionales del testículo y la vesícula seminal. Ratas macho adultas se dividieron en grupos control y grupo con MTX $(\mathrm{n}=12)$. En 30 días experimentales, a los animales tratados se les inyectó MTX (cola i.v., $75 \mathrm{mg}$ / $\mathrm{KgBW}$ ) los días 8 y 15. Luego, se examinaron los parámetros reproductivos y la histología de ambos grupos. Se analizó el espesor del epitelio de la vesícula seminal. Además, se investigaron las expresiones de la proteína tirosina testicular fosforilada y de la 
proteína reguladora aguda esteroidogénica (StAR). Los resultados mostraron que el MTX podría disminuir significativamente la concentración de espermatozoides epididimarios. Además, se observó la degeneración de las células germinales, el aumento de los espacios de los tejidos intersticiales y la baja densidad de masa del espermatozoide epididimal en el grupo de MTX. El grosor del epitelio de la vesícula seminal en el grupo MTX fue significativamente menor que el del grupo control. Además, la intensidad de las proteínas testiculares fosforiladas de 31, 32, 72 y 85 kDas aumentó significativamente, mientras que la de 42 y $47 \mathrm{kDas}$ en el grupo MTX disminuyó en comparación con el control. La expresión de la proteína StAR testicular en el grupo MTX también se redujo significativamente en comparación con el control. En conclusión, el MTX afecta los tejidos testiculares y seminales y cambia las proteínas funcionales testiculares en ratas adultas.

PALABRAS CLAVE: Metotrexato; Proteínas fosforiladas; Testiculo; Vesícula seminal; Rata macho.

\section{REFERENCES}

Akindele, O. O.; Kunle-Alabi, O. T.; Oghenetega, B. O.; Adeyemi, D. H. \& Raji, Y. Effects of methotrexate on serum testosterone level in sleep deprived male Wistar rats. Afr. J. Med. Med. Sci., 44(2):145-50, 2015.

Argyriou, A. A.; Bruna, J.; Marmiroli, P. \& Cavaletti, G. Chemotherapyinduced peripheral neurotoxicity (CIPN): an update. Crit. Rev. Oncol. Hematol., 82(1):51-77, 2012.

Arun, S.; Burawat, J.; Sukhorum, W.; Sampannang, A.; Maneenin, C. \& Iamsaard, S. Chronic restraint stress induces sperm acrosome reaction and changes in testicular tyrosine phosphorylated proteins in rats. Int. J. Reprod. Biomed. (Yazd.), 14(7):443-52, 2016 a.

Arun, S.; Burawat, J.; Sukhorum, W.; Sampannang, A.; Uabundit, N. \& Iamsaard, S. Changes of testicular phosphorylated proteins in response to restraint stress in male rats. J. Zhejiang Univ. Sci. B, 17(1):21-9, 2016 b.

Blumenfeld, Z. Chemotherapy and fertility. Best Pract. Res. Clin. Obstet. Gynaecol., 26(3):379-90, 2012.

Chelab, K. G. \& Majeed, S. K. Histopathological effects of methotrexate on male and female reproductive organs in white mice. Bas. J. Vet. Res., 8(2):166-75, 2009.

Gibson, R. J. \& Bowen, J. M. Biomarkers of regimen-related mucosal injury. Cancer Treat. Rev., 37(6):487-93, 2011

Iamsaard, S.; Burawat, J.; Kanla, P.; Arun, S.; Sukhorum, W.; Sripanidkulchai, B.; Uabundit, N.; Wattathorn, J.; Hipkaeo, W.; Fongmoon, D. \& Kondo, H. Antioxidant activity and protective effect of Clitoria ternatea flower extract on testicular damage induced by ketoconazole in rats. J. Zhejiang Univ. Sci. B, 15(6):548-55, 2014.

Iamsaard, S.; Sukhorum, W.; Sampannang, A. \& Sripanidkulchai, B. Protective effect of Momordica cochinchinensis (L.) Spreng aril extract on essential testicular markers in rats induced with valproic acid. Int. J. Morphol., 35(3):992-9, 2017.

Johnson, F. E.; Farr, S. A.; Mawad, M. \& Woo, Y. C. Testicular cytotoxicity of intravenous methotrexate in rats. J. Surg. Oncol., 55(3):175-8, 1994.

Kim, J. C.; Kim, K. H. \& Chung, M. K. Testicular cytotoxicity of DA-125, a new anthracycline anticancer agent, in rats. Reprod. Toxicol., 13(5):391-7, 1999.

Maremanda, K. P. \& Jena, G. B. Methotrexate-induced germ cell toxicity and the important role of zinc and SOD1: Investigation of molecular mechanisms. Biochem. Biophys. Res. Commun., 483(1):596-601, 2017.

Mitropoulos, D.; Patris, E.; Deliconstantinos, G.; Kyroudi-Voulgari, A.;
Anastasiou, I. \& Perea, D. Terazosin-induced alterations in catalase expression and lipid peroxidation in the rat seminal vesicles. Andrologia, 45(2):128-34, 2013

Padmanabhan, S.; Tripathi, D. N.; Vikram, A.; Ramarao, P. \& Jena, G. B. Cytotoxic and genotoxic effects of methotrexate in germ cells of male Swiss mice. Mutat. Res., 655(1-2):59-67, 2008.

Padmanabhan, S.; Tripathi, D. N.; Vikram, A.; Ramarao, P. \& Jena, G. B. Methotrexate-induced cytotoxicity and genotoxicity in germ cells of mice: intervention of folic and folinic acid. Mutat. Res., 673(1):43-52, 2009.

Saxena, A. K.; Singh, D. \& Singh, G. Structural interaction between drug DNA and protein - A novel approach for bioinformatics in medicine. Biomed. Res. (India), 20(1):28-34, 2009.

Schilsky, R. L.; Bailey, B. D. \& Chabner, B. A. Methotrexate polyglutamate synthesis by cultured human breast cancer cells. Proc. Natl. Acad. Sci. U. S. A., 77(5):2919-22, 1980.

Shrestha, S.; Dhungel, S.; Saxena, A. K.; Bhattacharya, S. \& Maskey, D. Effect of methotrexate (MTX) administration on spermatogenesis: an experimental on animal model. Nepal Med. Coll. J., 9(4):230-3, 2007.

Sukhorum, W. \& Iamsaard, S. Changes in testicular function proteins and sperm acrosome status in rats treated with valproic acid. Reprod. Fertil. Dev., 29(8):1585-92, 2017.

Sukhotnik, I.; Nativ, O.; Roitburt, A.; Bejar, D.; Coran, A. G.; Mogilner, J. G. \& Nativ, O. Methotrexate induces germ cell apoptosis and impairs spermatogenesis in a rat. Pediatr. Surg. Int., 29(2):179-84, 2013.

Vardi, N.; Parlakpinar, H.; Ates, B.; Cetin, A. \& Otlu, A. Antiapoptotic and antioxidant effects of beta-carotene against methotrexate-induced testicular injury. Fertil. Steril., 92(6):2028-33, 2009.

Yulug, E.; Türedi, S.; Alver, A.; Türedi, S. \& Kahraman, C. Effects of resveratrol on methotrexate-induced testicular damage in rats. Sci. World J., 2013:489659, 2013

Corresponding author:

Dr. Sitthichai lamsaard \& Dr. Tarinee Sawatpanich

Department of Anatomy

Faculty of Medicine

Khon Kaen University

123 Mittraphap Road

Amphoe Muang

Khon Kaen 40002

THAILAND

E-mail: sittia@kku.ac.th

Received: 26-10-2017

Accepted: 16-01-2018 